\title{
RESENHAS
}

\section{O FUTURO DO SINDICALISMO NO BRASIL}

\section{NELSON GOMES \\ TEIXEIRA (org.) \\ São Paulo, Livraria Pioneira \\ Editora, 1990, 205 páginas.}

\section{Por Sérgio Amad Costa} Professor do Departamento de Fundamentos Sociais e Jurídicos da Administração da EAESP/FGV e autor de livros sobre assuntos sindicais.

A Fundação FIDES (Fundação Instituto de Desenvolvimento Empresarial e Social) organizou no ano passado um simpósio internacional sobre questões sindicais. Os debates foram realizados em São Paulo, Salvador e Rio de Janeiro, com a participação de dirigentes sindicais europeus e brasileiros, sob a coordenação técnica do professor Leôncio Martins Rodrigues.

Os resultados do simpósio estão agora reunidos em livro, organizado pelo professor Nelson Gomes Teixeira. Trata-se de $\mathrm{O}$ Futuro do Sindicalismo no Brasil, lançado pela Livraria Pioneira Editora, com 205 páginas, dividido em três partes: visão européia, panorama brasileiro, e perspectivas do diálogo social no Brasil.

Os capítulos mais originais são os que versam sobre o sindicalismo europeu, com textos de dirigentes de órgãos de representação profissio- nal, tanto da área patronal, quanto da dos empregados.

Todos os depoimentos aqui reunidos são importantes, pois contribuem para conhecermos um pouco mais sobre relações trabalhistas de países desenvolvidos. Entretanto, a nosso ver, o que mais desperta interesse imediato para nós são os relatos a respeito do sindicalismo na Espanha e na Alemanha.

A experiência espanhola tocanos mais de perto pelo fato de os autores abordarem o comportamento dos sindicatos frente ao Pacto de Moncloa. Trata-se de uma lição para o Brasil que há muito procura, sem êxito, um entendimento nacional.

Portanto, é importante, no nosso caso, aprender um pouco com ou tras nações que passaram por experiências de pactos sociais bem-sucedidos e, assim, verificar que eles também não foram firmados com facilidade. E, sem dúvida, um acordo nacional que serviu de exemplo para a modernidade foi $\mathrm{o}$ Pacto de Moncloa, na Espanha.

Tal entendimento, como mostra o livro, ao contrário do que muitos pensam, não surgiu da noite para o dia e nem foi assinado num contexto de passividade das instituições sociais. Pelo contrário, as contradições foram colocadas na mesa de negociação e os espanhóis levaram um bom tempo até se firmax o acordo.

O processo de entendimento nacional durou mais de 15 meses. Desde meados de 1977 até o final de
1978, foi discutido um conjunto de medidas diversificadas para a redução e o controle da inflação que, na época, era de aproximadamente $26 \%$ anuais. E, em 1979, surgiu o Acordo Básico Interconfederal (ABI), entre organizações empresariais e sindicatos dos trabalhadores, impondo princípios de racionalização dos direitos trabalhistas.

O Pacto de Moncloa, no que se refere ao combate à inflação, estabeleceu, em linhas gerais, a desvalorização da moeda, a redução dos gastos públicos, o controle da expansão monetária mediante racionalização de crédito e o reajuste salarial com bases nos índices da inflação prevista (para o ano seguinte).

O pacto resultou em êxito para a economia espanhola, mesmo com falhas e o não cumprimento de algumas promessas feitas pelo governo, no sentido de compensar as perdas dos assalariados, causadas pelos ajustes da economia promovidos pelo entendimento nacional. Portanto, vale perceber que nem tudo saiu às mil maravilhas no pacto. Porém, como revela o livro, a economia espanhola, a partir de 1979, deu um grande salto quantitativo e qualitativo como resultado daquele entendimento nacional.

Evidentemente a situação do Brasil não é igual à da Espanha nos anos 70. As diferenças são profundas. Lá havia apenas trinta e oito milhões de habitantes, novecentos 
mil desempregados e uma inflação anual de $26 \%$. Mas o que se pode aprender, com esses relatos de dirigentes sindicais espanhóis, é que, em alguns momentos da história de uma nação, apesar de todas as divergências políticas e contradições sociais, a única saída democrática e viável para evitar o colapso da economia é a formação de um verdadeiro pacto social.

Outra experiência apresentada na obra, que nos interessa de perto, é a alemã, por ser um exemplo de sistema fundado no espírito de cooperação. E, sem dúvida, este é o clima trabalhista que precisamos ter no Brasil.

Antes de mais nada, cumpre assinalar que, na Alemanha, os trabalhadores, juntamente com os empresários, num processo harmôni$\mathrm{CO}$, vivem, nas grandes empresas, sob um sistema de cogestão (consubstanciado na Lei de $11 / 10 / 52$, reformado em 1972 e completado em 1976) que assegura, para valer, a paridade de representação entre empregados e acionistas nos conselhos de superintendência das organizações produtivas. Ali, há anos, como verdadeiros parceiros, garantem os benefícios tanto dos trabalhadores quanto das empresas.

O livro aponta que o conceito de participação social naquele país caracteriza e define as relações de trabalho. Empresas e sindicatos não se vêem como oposições entre empregadores e empregados num cenário de luta de classes, mas, sim, como parceria. "Substituínos a palavra confrontação pela palaura cooperação, como receita para a melhoria do bem-estar social" (página 110).

Outro aspecto importante observado nos sindicatos da Alemanha é que eles, apesar de poderosos e fortes, não substituem os partidos políticos. Ou seja, há uma total independência dos órgãos de representação profissional em relação às agremiações políticas e os parceiros das discussões dos sindicatos são unicamente os empregadores $\mathrm{e}$ mais ninguém.

O fato é que a Alemanha, com um sistema de representação profissional extremamente forte, trabalhando sob um regime de parceria entre empregados e empregadores, é, hoje, um exemplo de desenvolvimento econômico não só para o Brasil, mas, também, para o mundo inteiro.

Ressaltamos, deste livro, os casos da Espanha e da Alemanha por julgarmos serem experiências dignas de reflexões, em virtude do conjunto de atitudes mútuas (adotadas tanto por empregados quanto por empregadores) visando ao bem-estar social de seus países, verdadeiras lições para nós que ainda vivemos sob um sindicalismo de tipo corporativo, antítese do moderno, que só faz manter o "círculo vicioso da miséria".

Ao analisar esse "círculo", o professor Leôncio Martins Rodrigues encerra os capítulos do livro: "Crise econômica, social, greves, mais inflação, mais crises, mais greves e assim sucessivamente. A este quadro atual, eu temo que a nossa frágil democracia não resistirá e deve ser evitado a todo o custo. $\hat{E}$ preciso mudança de atitude por parte dos trabalhadores, mas é necessária também uma mudança por parte dos empresários. Afinal de contas, as relaçōes entre capital e trabalho são relações que dependem de ações mútuas. Embora acredite que este periodo imediato seja marcado por graves dificuldades, penso que devemos voluntariamente, intencionalmente, agir no sentido de evitar o círculo vicioso da miséria" (página 205). $\square$

\section{DEUSES DAA ADMINISTRAÇÃD, TRANSFORMANDO AS ORGANIZAÇÕES}

\section{CHARLES HANDY}

São Paulo,Vértice, Editora dos Tribunais, Biblioteca da Gerência e Administração, 1987, 245 páginas.

\section{9or Fernando C. Prestes Motta}

Professor Titular do

Departamento de

Administração Geral e

Recursos Humanos da

$\mathrm{EAESP} / \mathrm{FGV}$.

harles Handy é conhecido na
Europa, sobretudo, por pro-
gramas de rádio e televisão. De fato,
seu estilo lembra esses veículos,
mais que os livros acadêmicos. Mes-
mo assim, é possível que ouvintes
de rádio e telespectadores pouco
acostumados à leitura tirem
proveito de Deuses da Administração,
tanto quanto profissionais e schol-

